\title{
Collagen Scaffold and Lipoaspirate Fluid - derived Stem Cells for the Treatment of Cartilage Defects in a Rabbit Model
}

\author{
HOREA RARES CIPRIAN BENEA ${ }^{\#}$, KAMEL EARAR ${ }^{2 *}$, WANDA LATTANZI ${ }^{\#}$, VITTORIO QUERCIA 4 , CRISTIAN BERCE ${ }^{5}$, \\ OLGA SORITAU ${ }^{6}$, MARISTELLA SACCOMANNO ${ }^{7}$, GIUSEPPE MILANO ${ }^{7}$, GHEORGHE TOMOAIA ${ }^{1}$, DIANA CERCHIZAN ${ }^{8}$, \\ AUREL MOHAN ${ }^{9}$ \\ IIuliu Hatieganu University of Medicine and Pharmacy, $8^{\text {th }}$ Department, Orthopedics and Traumatology Discipline, 47 Traian \\ Mosoiu Str., 400132, Cluj Napoca, Romania \\ 2Dunarea de J os University of Galati, Medicine and Pharmacy Faculty, 47 Domneasca Str., 800008, Galati, Romania \\ ${ }^{3}$ Catholic University, Institute of Anatomy and Cell Biology, Latium Musculoskeletal Tissue Bank, 28 Via Garibaldi, Rome, \\ Italy \\ ${ }^{4}$ Catholic University, Institute of Anatomy and Cell Biology, 28 Via Garibaldi, Rome, Italy \\ 5Iuliu Hatieganu University of Medicine and Pharmacy, Center for Experimental Medicine, 6 Louis Pasteur Str., 400349, Cluj \\ Napoca, Romania \\ ${ }^{6}$ Ion Chiricuta Institute of Oncology, 34-36 Republicii Str., 400015, Cluj Napoca, Romania \\ ${ }^{7}$ Catholic University, Institute of Orthopedics and Traumatology, 28 Via Garibaldi, Rome, Italy \\ 8University of Medicine and Pharmacy of Tirgu Mures, $38 \mathrm{Gh}$. Marinescu, Str., 540139, Tirgu Mures, Romania \\ 'University of Oradea, 1 Universitatii Str., 410087, Oradea, Romania
}

\begin{abstract}
The purpose of the present study was to assess and compare the chondroregenerative properties of PLA (processed lipoaspirate) and LAF (lipoaspirate fluid) cells, in a preclinical rabbit model of knee cartilage defect. The defects were repaired by a collagen I/III scaffold and added LAF-cells, PLA-cells or no cells, upon the study group. The results showed that collagen scaffolds seeded with LAF-derived stem cells appear to have slightly better activity and outcomes when compared to PLA-cells, in terms of cartilage regeneration.
\end{abstract}

Keywords: Collagen, scaffold, stem cells, cartilage, regeneration

Articular cartilage restoration by hyaline-like tissue formation still represents a challenge for surgeons and researchers [1-3]. Stromal stem cells (i.e. somatic multipotent precursors residing in perivascular locations of the connective stroma in adult tissues) are believed to represent a valid option for cartilage repair, due to their potential ability to express specific molecular markers, continuously release of grow th factors and to differentiate into the chondrogenic lineage [1]. In particular, most of the clinical and experimental studies performed to date use bone-marrow stromal cells (BMSCs), as the physiologically reasonable candidates for chondrocyte regeneration [4-6]. Nonetheless, the scarcity of tissue source availability in adults, along with the relatively invasive harvesting and the reduced cellular yield makes the bone marrow an inefficient stem cell source for articular cartilage restoration. During recent years, stromal stem cells residing in the vascular-stromal fraction of the adipose tissue are being proposed as a valid alternative, due to their wider availability and comparable plastic properties. Adipose tissue (AT) is indeed an excellent source for high yield of mesenchymal stem cells (namely, adipose-derived stem cells, ASCs), with an average yield of approximately 5,000 fibroblast colony-forming units (CFU-F) per gram of AT, compared with estimates of approximately 100-1,000 CFU-F per milliliter of bone marrow [6].

Moreover, AT requires minimally-invasive harvesting procedure. However, most of the procedures based on these cells are time consuming, technically demanding, require multiple interventions and ex-vivo manipulation, thus implying high costs and risks of sample and surgical site contamination. The ideal procedure should be a one stage intervention with minimal tissue manipulation. Lately it was advocated the possibility of obtaining stem cells directly from the liquid portion of the lipoaspirate (lipoaspirate fluid, LAF), by rather simple mechanical procedures, and these cells may be theoretically useful and valuable for cell-based therapies as well as those obtained from laboratory processed lipoaspirate (PLA) $[5,6]$. Very few reports on the in vivo regenerative potential of LAF cells are available in current literature and no evidence exists on the differences between LAF- and PLAderived cells in promoting articular cartilage repair [6-8]. The purpose of the present study was to assess and compare the chondroregenerative properties of PLA- and LAF-cells seeded collagen scaffolds, in a preclinical rabbit model of knee cartilage defect. The hypothesis of the study was that LAF would promote better hyaline cartilage restoration with beneficial trophic effects due to the presence of plastic stem cells along with soluble molecules.

\section{Experimental part}

Materials and methods

The present study was designed as a pilot study. All experiments were conducted in accordance with the guidelines and approved by the local Ethics Committee (luliu Hatieganu University of Medicine and Pharmacy from Cluj-Napoca, Romania; authorization number 340/ 02.06.2015). 


\section{Studypopulation}

Nine male Crl:KBL adultNew Zealand white rabbits with a mean age of 12 months and weight of 3.75 kilograms $(\mathrm{kg})$ (range 3.3 to $4.1 \mathrm{~kg}$ ) were used in the present study. Prior to the onset of the study, all animals were quarantined and left to acclimatize for 14 days. Before and after surgery, animals were housed in standard stacked cages as one individual per cage and had access to filter tap water in bottles and pelleted food.

\section{Cell harvesting and isolation}

Adipose tissue was obtained from Hoffa pad during total knee replacement in a 55 years old male healthy human donor (who signed the informed consent stating the utilization of biological samples for research purposes), split into two aliquots and alternatively processed using either enzymatic treatment and centrifugation, or using the MyStem EVO ${ }^{\circledR}$ kit (Bi-Medica Srl, Treviolo, Italy) to separate fatty and LAF portions (fig. 1) [6]. Cells were counted and then they were plated for isolating the adherent CD105+ cells.

ASCs isolated from adipose tissue through standard collagenase digestion (PLA cells) [7] and ASCs isolated from LAF, were cultivated in $25 \mathrm{~cm}^{2}$ Cole flasks in incubator with $5 \% \mathrm{CO}_{\text {, }}$ humidity $90 \%$ and expanded for 2-3 passages. The cultivation medium consisted in DMEM with $4.5 \mathrm{~g} / \mathrm{L}$ glucose, $1 \%$ antibiotics, $2 \mathrm{mM}$ L-glutamine and $10 \% \mathrm{FBS}$.

\section{Cell seeding of collagen scaffolds}

To perform in-vivo implantation, the cells were detached from the plastic plates by trypsinisation as follows: culture medium was discarded and the adherent cell layer was washed with sterile PBS. Two millilitres of trypsin $0.25 \%$ / EDTA solution were added in the culture flasks and after 2$3 \mathrm{~min}$, when the cells detached, $5 \mathrm{~mL}$ of complete medium were added. The cell suspension was transferred into a 15 $\mathrm{mL}$ centrifuge Falcon tube and centrifuged at $1200 \mathrm{rpm}$ for 5 min.

The cells were re-suspended in $1 \mathrm{~mL}$ of complete medium and counted with a Thoma haemocytometer. Sterile collagen I/III membranes (Chondro-Gide ${ }^{\circledR}$; Geistlich Pharma AG, Wolhusen, Switzerland) of $6 \mathrm{~mm}$ diameter were placed in Petri dishes and $1 \times 10^{5} \mathrm{LAF}$ and PLA cells were added alternatively to each plate. The cell-

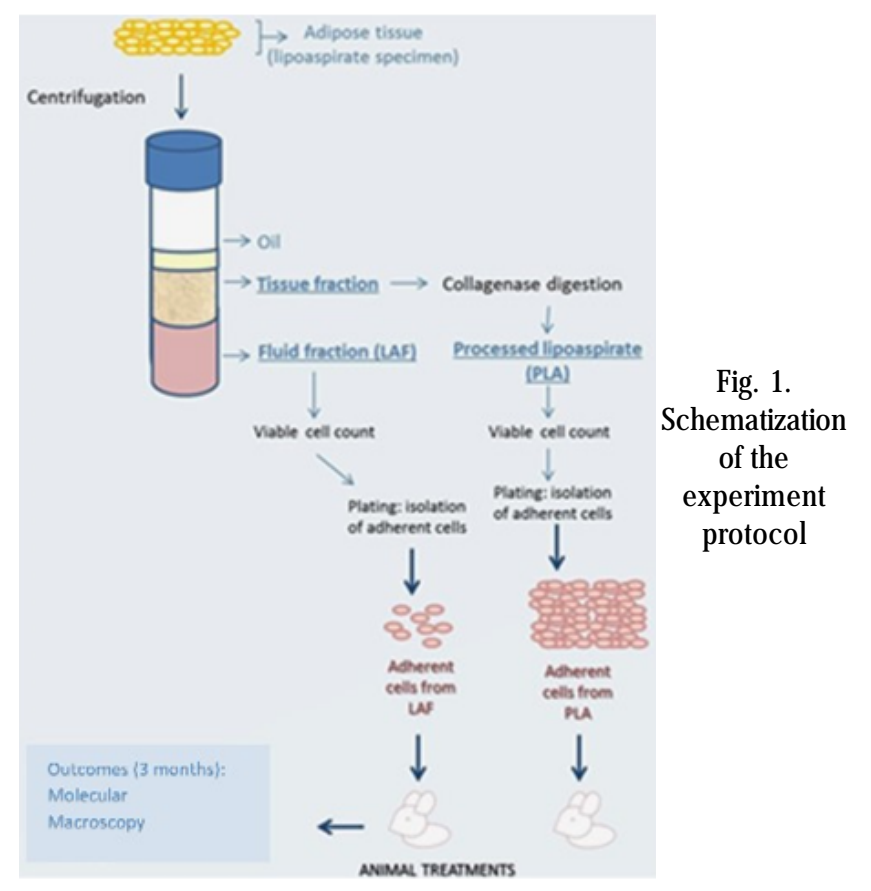

seeded collagen membranes were visualized in phase contrast microscopy after $24 \mathrm{~h}$ (fig. 2).

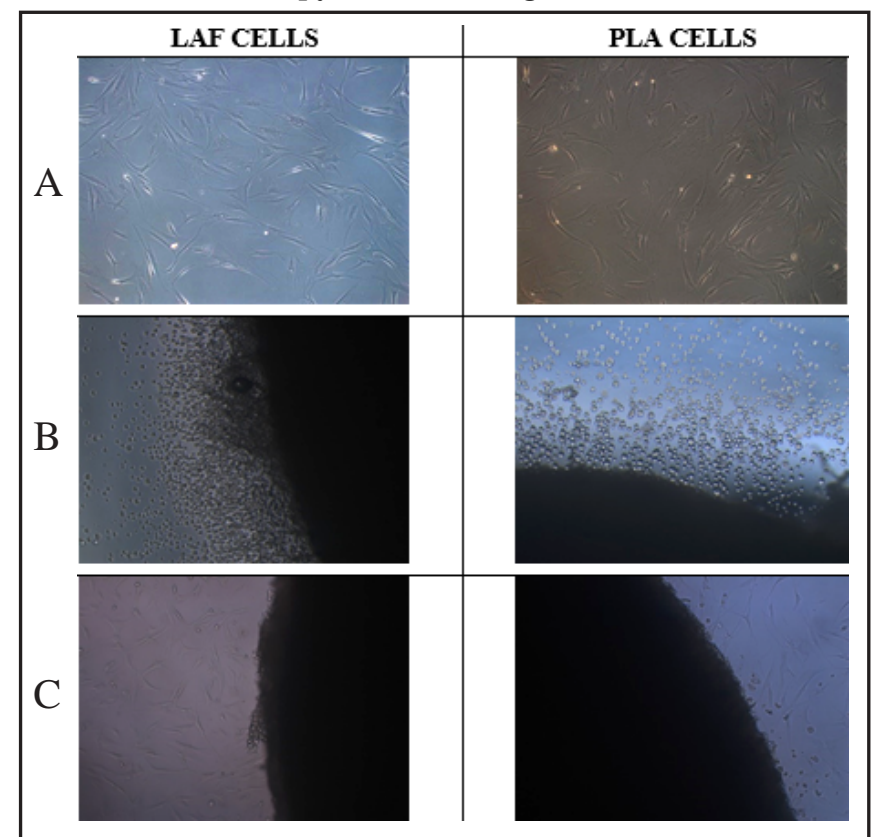

Fig. 2. Phase contrast microscopy images of the cells seeded on the membrane A. Cells at $4^{\text {th }}$ passage, before seeding

B. Collagen membrane seeded with cells, images taken $30 \mathrm{~min}$. after seeding $\mathrm{C}$. Cells on collagen membrane, $20 \mathrm{~h}$ after seeding

\section{Interventions}

All the surgical procedures were performed under general anesthesia and by use of sterile conditions. The rabbits were anesthetized using diazepam with a dosage of $1 \mathrm{mg} / \mathrm{kg}$, followed by ketamine $35 \mathrm{mg} / \mathrm{kg}$ and xylazine 5 $\mathrm{mg} / \mathrm{kg}$. A local subcutaneous infiltration with bupivacaine was also done.

A medial parapatellar incision in the rightknee was done to expose the joint. With the aim of a biopsy punch needle and a drill bit, a 6-mm wide and 3-mm deep osteochondral defect was created in the femoral trochlea (fig. 3).

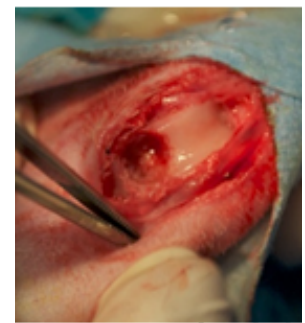

Fig. 3. Osteochondral defect created in the femoral trochlea
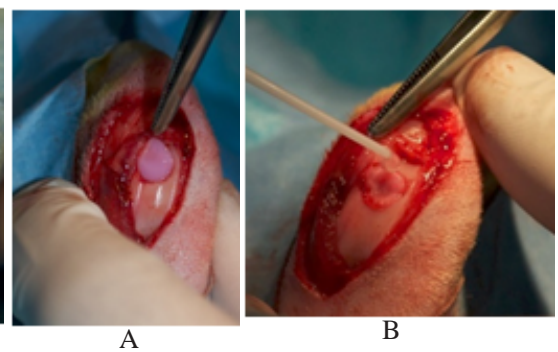

Fig. 4. Filling of the $\operatorname{defect}(A)$ and sealing the scaffold with fibrin glue (B)
Animals were divided into three groups, consisting of three animals each, according to treatment: in group $A$ (control group), the defect was filled with unseeded collagen scaffold (ChondroGide $®$ ); in group B the scaffold was seeded with LAF cells and in group C with PLA cells (fig. 4).

In all the cases, the scaffold was fitted into the defect and glued in place with a fibrin sealant (Tisseel Lyo $®$; Baxter, Deerfield, IL, USA). Surgical wound closure was performed in anatomical layers, with 3-0 poliglycolic acid sutures and without drainage.

The animals received postoperative medication: tramadol hydrochloride at a dosage of $2 \mathrm{mg} / \mathrm{kg}$ each day for 7 days, meloxicam $0.5 \mathrm{mg} / \mathrm{kg}$ for 3 days and enrofloxacin $10 \mathrm{mg} / \mathrm{kg}$ for 7 days. After surgery, the rabbits were returned to their cages without any immobilization 
Table 1

WAYNE SCORING SYSTEM FOR CARTILAGE REPAIR MACROSCOPIC EVALUATION [8]

\begin{tabular}{|c|c|}
\hline Gross appearance & Grade \\
\hline Coverage & 4 \\
$>75 \%$ fill & 3 \\
$50-75 \%$ fill & 2 \\
$25-50 \%$ fill & 1 \\
$<25 \%$ fill & 0 \\
No fill & \\
Neocartilage color & 4 \\
Normal & 3 \\
$25 \%$ yellow/brown & 2 \\
$50 \%$ yellow/brown & 1 \\
$75 \%$ yellow/brown & 0 \\
$100 \%$ yellow/brown & \\
Defect margins & 3 \\
Invisible & 2 \\
$25 \%$ circumference visible & 16 \\
$50 \%$ circumference visible & 0 \\
$75 \%$ circumference visible & \\
Entire circumference visible & \\
Surface & \\
Smooth/level with normal & \\
Smooth but raised & \\
Irregular 25-50\% & \\
Irregular 50-75\% & \\
Irregular 75\% & \\
\hline TOTAL & \\
\hline
\end{tabular}

of the operated limb and full weight-bearing was allowed as tolerated. General health and weight-bearing status was monitored during recovery.

\section{Outcome measurements}

Animals were euthanized three months after surgery, by anesthetizing them using the protocol described above and followed by an intravenous injection of potassium chloride. The distal femur was dissected and removed. With the use of a micro saw, two samples were taken from each rabbit. One sample was sunk immediately in liquid nitrogen for further molecular analysis, and the other one was fixed in $4 \%$ paraformaldehyde for morphological studies.

The main endpoints of the study were the quantitative analysis of cartilage proliferation gene expression and of macroscopic aspect according to the Wayne Cartilage Repair Score [8] (table 1). Histological qualitative evaluation and surveillance of complications were also performed, as this technique is usually used for tissue evaluation [8-14].

After $24-h$ incubation with $4 \%$ paraformaldehyde buffered in PBS at $4^{\circ} \mathrm{C}$ and $\mathrm{pH} 7.5$, the samples were washed in water for one hour and then decalcified for 15 days dehydrated and embedded in paraffin. Tissue samples were then cut into 15-im thick sections using a microtome and stained with Alcian Blue for cartilage tissue analysis [15-18].

In order to evaluate the formation of cartilage components, quantitative real-time polymerase chain reaction (qPCR) was used to analyse the expression of genes involved in cartilage differentiation. To this aim, total RNA was isolated from the nitrogen frozen samples of the three groups, plated into 6-well plates, using the RNeasy MiniElute Cleanup Kit (Qiagen, Valencia, CA, USA), according to the manufacturer's instructions, as previously described [19-21]. An additional on-column DNAse incubation step was performed to allow the selective removal of genomic DNA during the isolation process. Thereafter, two-step reverse transcription and qPCR were carried out as previously described [19,22, 23]. The resulting CDNA was used as template for $\mathrm{PPCR}$, to analyse the expression of genes encoding alphal chains of type II collagen (COL2A1), Aggrecan (ACAN) and transcription factor SOX-9, all involved in cartilage differentiation. The 2ÄÄCtmethod [23] was applied to calculate fold differences in gene expression using the housekeeping gene glyceraldehyde 3-phosphate dehydrogenase (GAPDH) for data normalization. PCR products were subjected to melting curve analysis to rule out synthesis of unspecific products. The oligonucleotide primers were designed using Primer 3 software (http://bioinfo.ut.ee/primer3-0.4.0/).

\section{Data analysis}

Continuous outcomes were analyzed in order to assess significant differences between groups. For gene expression analysis a simple t-test was performed. For the macroscopical scoring a two-way analysis of variance (ANOVA) with Bonferroni post hoc test to compare replicate means by rows (the parameters of Wayne score: coverage, color, margins and surface) and a one-way ANOVA with Tukey's multiple comparison test to compare all columns (the means for each group), with the significance limit set at 0.05 (GraphPad Prism 7.02 Software).

\section{Results and discussions}

We encountered no important postoperative complications among the studied individuals, except for two cases with a local swelling which persisted for three weeks. The rabbits regained full function of their limb at 4 weeks, when they were able to walk without limping.

\section{Gene expression analysis}

Quantitative real time PCR - qPCR showed that the expression of the genes involved in cartilage differentiation was significantly stronger in LAF Group.

More explicit, in group $B$ the ACAN gene expression was the highest compared to group $A$ and $C(p<0.0005)$. Concerning the expression of COL2A1 and SOX-9 genes in group $B$, it was highly statistically significant greater in comparison with group $A(p<0.0005)$, and simply statistically significant greater when compared to group C $(p<0.05)$ (fig. 5).

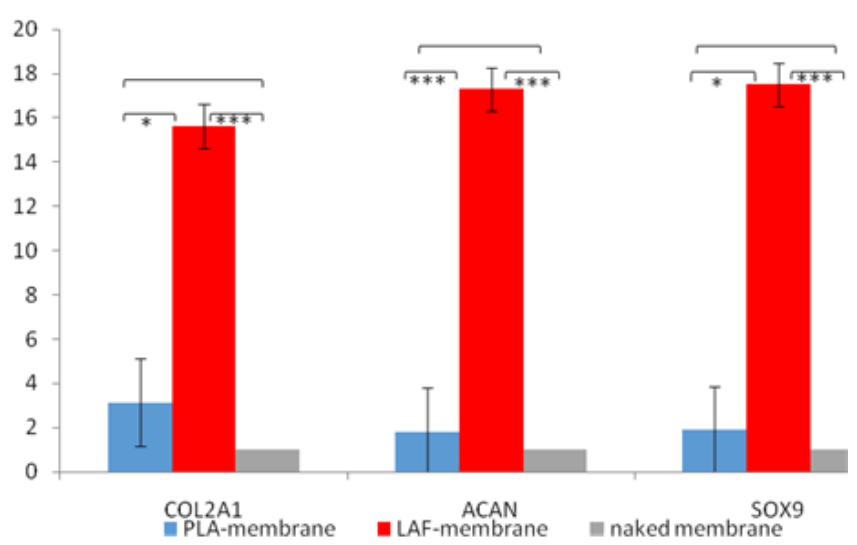

Fig. 5. Comparative expression of genes involved in cartilage differentiation ( $* p$ value $<0.05$; ** $p$ value $<0.005$; *** $p$ value $<0.0005)$ 

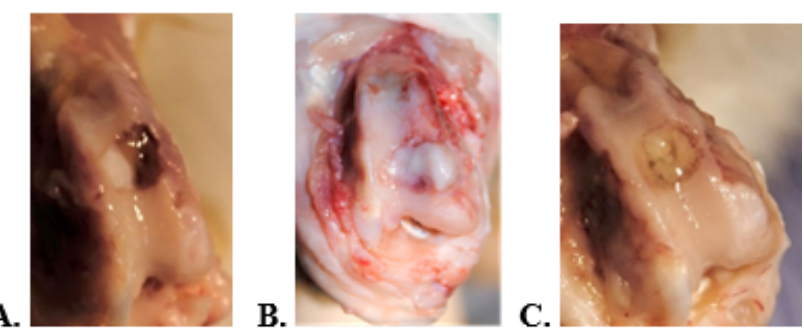

Fig. 6. Macroscopic aspects. A. Group A - control. B. Group B LAF. C. Group C - PLA.

\begin{tabular}{|c|c|c|c|c|c|c|c|c|r|}
\hline & \multicolumn{3}{|l}{ Group A-No ADSC } & \multicolumn{3}{c|}{ Group B-LAF } & \multicolumn{3}{c|}{ Group C-PLA } \\
\hline Rabbit no. & 1 & 2 & 3 & 1 & 2 & 3 & 1 & 2 & 3 \\
\hline Indiviual score & 6 & 8 & 7 & 12 & 10 & 12 & 10 & 12 & 11 \\
\hline Group score & & 7 & & & 11.3 & & 11 \\
\hline
\end{tabular}

\begin{tabular}{|l|c|c|c|c|c|}
\hline $\begin{array}{l}\text { Tukey's Multiple } \\
\text { Comparison Test }\end{array}$ & Mean Diff. & q & $\begin{array}{c}\text { Significant? } \\
\mathrm{P}<0.05 ?\end{array}$ & Summary & $95 \%$ CI of diff \\
\hline Group A vs Group B & -4.333 & 7.120 & Yes & $* *$ & -6.974 to -1.693 \\
\hline Group A vs Group C & -4.000 & 6.573 & Yes & $* *$ & -6.641 to -1.359 \\
\hline Group B vs Group C & 0.3333 & 0.5477 & No & ns & -2.307 to 2.974 \\
\hline
\end{tabular}

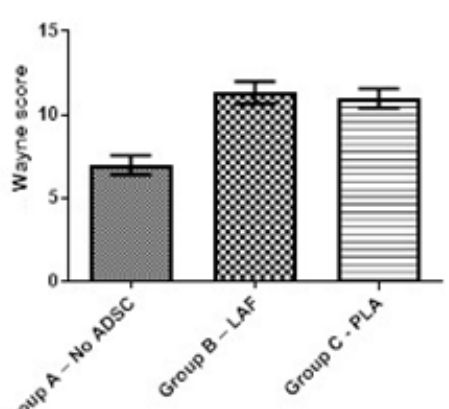

Fig. 7. Wayne scores in the three groups

Macroscopic evaluation

At the moment of sacrifice, we did not find any signs of local inflammation, infection or other pathological joint condition. The gross appearance seemed better for Group $B$, with a wider coverage of the defect by a more cartilaginous-like tissue (fig. 6).

The overall macroscopic evaluation of cartilage repair is presented in table 2 and figure 7. The highest value of the Wayne Score was obtained in the LAF group, a mean of 11.3 out of 16 points, with the ANOVA test showing a highly significant difference among groups $(p=0.0041)$. Tukey's multiple comparison test showed statistically significant differences between group $A$ and group $B$ and respectively group $C$, with no significant differences between group $B$ and $\mathrm{C}$ (table 3).

The macroscopic evaluation showed highly significant larger cartilage surface coverage $(p<0.001)$ and significantly smoother surface $(p<0.05)$ in group $B$ than in group $A$, and highly significant better cartilage coverage $(p<0.001)$ and color $(p<0.05)$ in group C comparatively to group A (fig. 8).
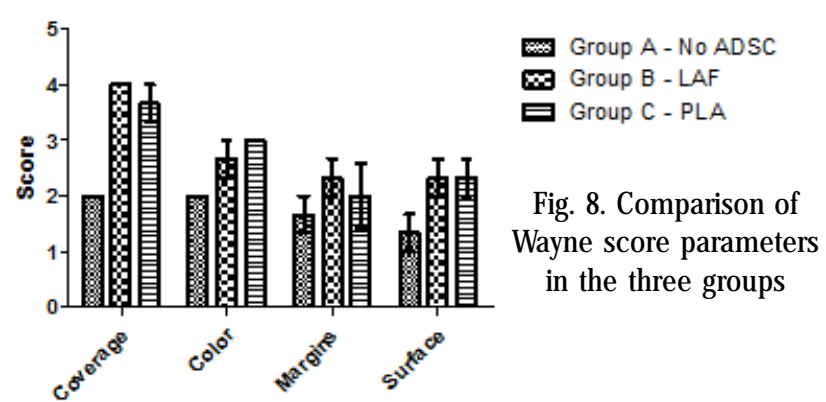

Highly significant larger cartilage surface coverage $(p<0.001)$ and significantly smoother surface $(p<0.05)$ in group $B$ than in group $A$, and highly significant better cartilage coverage $(p<0.001)$ and color $(p<0.05)$ in group C comparatively to group $A$.

\section{Histologic evaluation}

As we can see in figure 9.A the cartilage tissue is colored bright blue in Alcian Blue staining. The difference between cartilage tissue and bone tissue is remarkable. The cartilage tissue is rich in chondrocyte cells and matrix. Figure 9.B and 9.C show the rounded form of chondrocytes, assembled in groups of two or more, in a granular or almost homogeneous matrix.

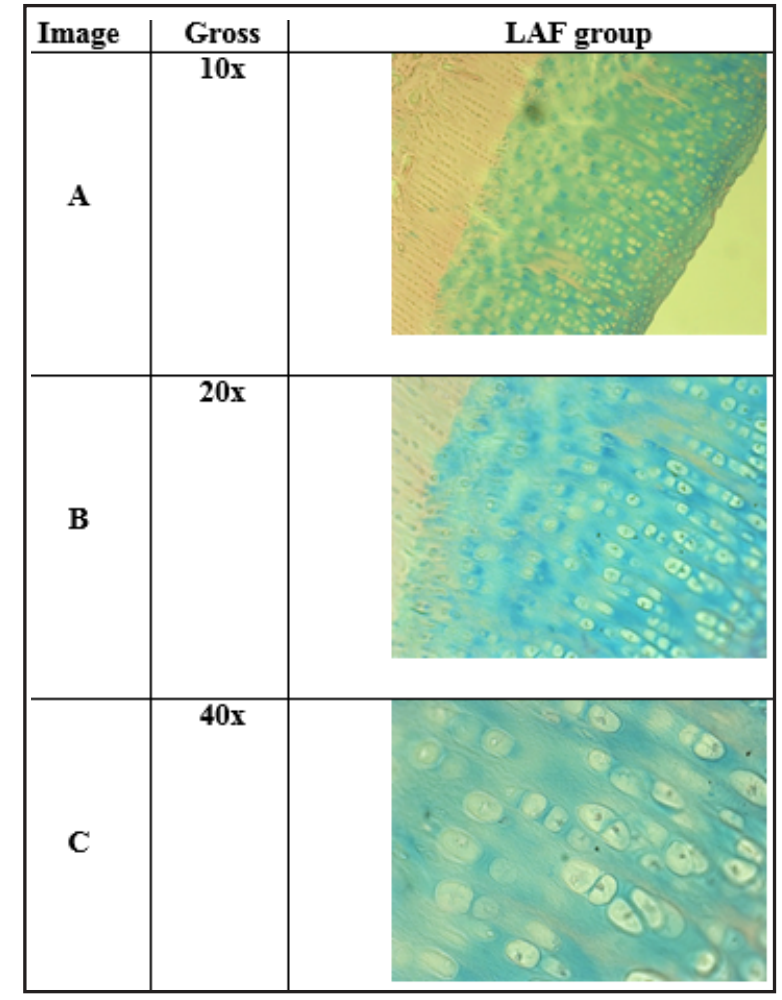

Fig. 9. Microscopic aspects of the regenerated articular cartilage in LAF group (images A-C)

We performed a qualitative analysis of the repaired tissue in the two groups with adipose derived stem cells, according to specific histologic parameters (fig. 10). According to the evaluation of group $B(L A F)$, we found the following:

-Comparable staining, thickness and alignment of the neocartilage in both groups, with almostcomplete bonding to the native cartilage and tidemark continuity

-More hyaline cartilage, with intact and more regular surface than in PLA group

-Lesser cellularity and disorganization, with fewer chondrocyte clusters comparative to PLA group

-Better reconstruction of the subchondral bone, with less fibrous tissue and almost complete bonding with adjacent bone.

These images are in agreement with gene expression analysis and macroscopic evaluation, showing the 


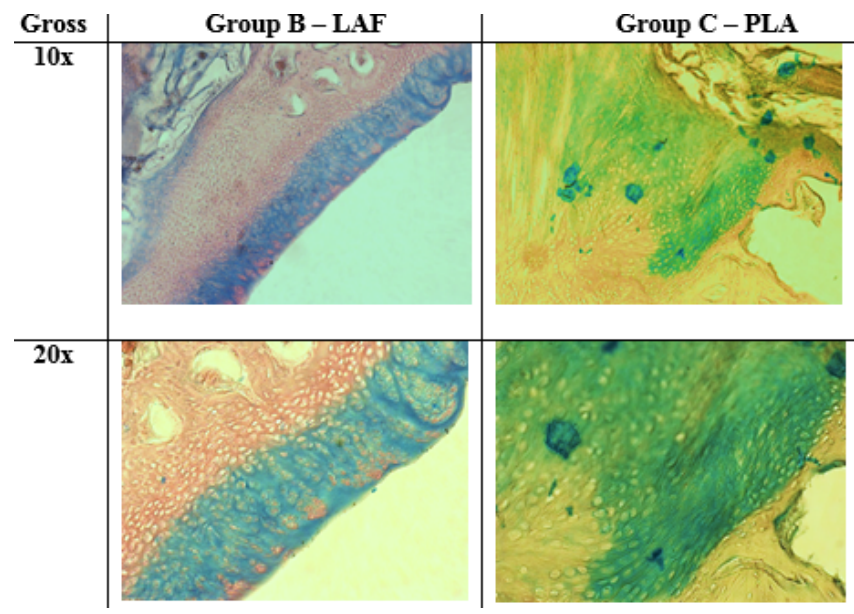

Fig. 10. Comparative microscopical aspects of cartilage formations in the two groups with adipose derived stem cells (Alcian Blue staining)

remarkable potential of LAF-cells to differentiate into cartilaginous tissue.

First of all, the results of our study show that, on an animal model, surgical therapies utilizing collagen scaffolds impregnated with mesenchymal stem cells can repair osteochondral defects in the knee joint. But the most important finding is that, in what concerns the articular cartilage restoration, minimally processed adipose derived stem cells from the lipoaspirate fluid portion (LAF-cells) can be at least as effective as stem cells obtained from laboratory processed lipoaspirate fraction (PLA-cells).

This finding is supported by the results obtained: the LAF group presented a significantly stronger expression of cartilage proliferation genes (qPCR), the best Wayne macroscopical score (11.3 points) and very good histological evaluation of the regenerated cartilage and subchondral bone.

Our study was justa pilot research and we are aware of some limitations. Although rabbit is widely used as small animal model [23-25], the translation to clinical human model may not be as accurate. Also, the small number of animals included didn't allow us to draw statistically powerful conclusions. We could not perform a micro-CT scan on all animals, although this method offers a good visualization of the regenerated tissue.

Adipose derived stem cells (ASCs) can be isolated in similar quantity and quality from both fatty and liquid portions of the lipoaspirate. It was not the purpose of this article to describe the isolation and culture of these cells, as it has been previously described [6,9], but to provide a practical evidence of their potential in-vivo use for osteochondral regeneration.

Osteochondral regeneration by adipose derived stem cells implantation, with different types of scaffolds, is reported in literature based on various in-vivo experiments but in almostall studies, ASCs are obtained from processing the stromal-vascular fraction (SVF) of the lipoaspirate (PLA). Reports about using LAF-cells for in-vivo experiments are scarce and particularly absent those regarding cartilage repairs. In this context, our study represents a novelty, and the results encourage us to continue the research in this field. The role of cells in cartilage regeneration is incontestable. As our results show, the groups with added ASCs present statistically significant better cartilage formation than the control group, where the collagen I/III membrane was implanted without adding cells, although with this method there are very good results reported in the literature [28-30]. The utilization of a validated chondrogenic scaffold (Chondro-Gide ${ }^{\circledR}$; Geistlich
Pharma AG, Wolhusen, Switzerland) [31-33] eliminated the risk of bias due to surgical procedure and implants.

Remarkable is the highly significant superior chondrogenic gene expression in the LAF group, which could mean that their activation, differentiation and proliferation capacities are much more powerful than those of PLA-cells $[34,35,36]$. This is probably due to the facts that LAF contains a number of trophic molecules and tissue fractions that cooperate with stem cells in exploiting regenerative properties and, the isolation process of PLAcells by collagenase digestion could decrease their performances. Even if the overall results of LAF-cells group seem only slightly better when compared to PLA group, the most important advantage is represented by their relative ease of harvesting, with minimal manipulation.

\section{Conclusions}

ASCs represent valuable options for osteochondral repair. LAF-derived stem cells appear to have slightly better activity and outcomes when compared to PLA-cells, in terms of cartilage regeneration. LAF-cells can be separated rapidly with minimal tissue manipulation, making them more cost-effective and suitable for one-stage surgical procedures.

Acknowledgments: MD Horea Benea, acknowledges the "Iuliu Hatieganu" University of Medicine and Pharmacy, $8^{\text {th }}$ Department of Surgical Specialties: Orthopedics and Traumatology, Cluj-Napoca, Romania, for the internal grant no. 4994/4/08.03.2016.

\section{References}

1.BOWEN R.E., Aesthetic Plast Surg., 40(3), 2016, p. 367-71.

2.ANDREI B., NICULESCU M., POPESCU GH., International Orthopaedics, 40(2), 2016, p.393-397.

3.ANTONIAC I. (Ed.) Handbook of Bioceramics and Biocomposites, Publisher Springer International Publishing Switzerland, NY, 2016, pp. 223.

4.BARBA M, CICIONE C, BERNARDINI C, MICHETTI F, LATTANZI W. Biomed Res Int., 2013, 2013, p. 416391.

5.YOSHIMURA K, SHIGEURA T, MATSUMOTO D, SATO T, TAKAKI Y, AIBA-KOJ IMA E et al. J Cell Physiol, 208(1), 2006, p. 64-76.

6.CICIONE C, DI TARANTO G, BARBA M, ISGRÒ MA, D'ALESSIO A, CERVELLI D, LATTANZI W et al., Plast.Reconstr.Surg., 137(4), 2016, p.1157-1167.

7.ORR J.S., KENNEDY A.J., HASTY A.H., Journal of Visualized Experiments,/ 75, 2013, p. 50707.

8.WAYNE J.S., MCDOWELL C.L., SHIELDS K.J ., TUAN R.S., AP Tissue Eng., 11(5-6), 2005, p. 953-63.

9.ANTONIAC I., NEGRUSOIU M., MARDARE M.; et al., Medicine. 96(19):e6687, 2017.

10.NICULESCU M, ANTONIAC I, VASILE E. et al., Mat. Plast., 53, no. 4, 2016, p.642-645.

11.GRECU D., ANTONIAC I., TRANTE 0. et al., Mat. Plast., 53, no. 4, 2016, p.776-780

12.BOTEZ P., SIRBU P., SIMION L. et al., EJOST, 19(6), 2009, p.387-395. 13.BRATILA E., COMANDASU D., MILEA C. et al.,J Adhes Sci Technol., 31(18), 2017, p.2028-2043.

14.ANTONIAC I., BURCEA M., IONESCU R.D., BALTA F., Mat. Plast., 52, no. 1, 2015, p.109

15.ISTRATE,B.,MUNTEANU,C.,CRIMU,C.I,IACOB,S.S.,MARCELIN,B.,KAMEL,E., Morphological and tribological aspects of some ZrO2 coatings on MgCa biodegradable alloys,Indian J ournal of Engineering and materials sciences, 23(6), 2016: 418-424

16.ANCUTA,C., ANCUTA,E., CHIRIEAC,R., ANTOHE, M., IORDACHE,C., Anti-Tumor Necrosis Factor Alpha Therapy and Periodontal Inflammation in Rheumatoid Arthritis A clinical and biochemical approach,Rev. Chim. (Bucharest), 68, no. 2, p. 369

17.CRACIUNESCU E., SINESCU C., NEGRUTIU M.L. et al., J Adhes Sci Technol., 30(6), 2016, p. 666-676. 
18. PARIZA, G., MAVRODIN, C.I., ANTONIAC, I., Mat. Plast., 52, no. 4, 2015, p.484

19.CIRSTOIU, M., CIRSTOIU C., ANTONIAC I., MUNTEANU O., Mat. Plast., 52, no. 3, 2015, p.25

20.MARINESCU R., ANTONIAC, I., LAPTOIU, D., ANTONIAC, A., GRECU, D., Mat. Plast., 52, no. 3, 2015, p.340

21.BARBA I, VILLACORTA E, BRATOS-PEREZ MA, etal., Rev Esp Cardiol (Engl Ed), 65(9), 2012, p. 813-818.

22. ANTOHE,M.E., AGOP FORNA, D., ANDRONACHE, M., FEIER R. FORNA, N.C., Aspects of the therapy of partially extended edentation using modern methods - attachments as maintenance, support and stabilization, Romanian Journal of Oral Rehabilitation, Vol. 8, No. 2 April - June 2016, pp16-25

23. IOSIFESCU A.G., MOLDOVAN H., ILIESCU V.A., J Heart Valve Dis., 23(2), 2014, p.149-157.

24. GRADINARU, I., TIMOFTE,D.,VASINCU, D.,TELSOIANU,D., CIMPOESU,D., MANOLE,V., GHEUCA-SOLOVASTRU,L., Preliminary Results on Pulsed Laser Deposition of PMMA on Nitinol Substrate,Mat. Plast., 51, no. 3, 2014, p.230

25.YOSHIMURA K., SHIGEURA T., MATSUMOTO D., et al., AB J Cell Physiol., 208(1), 2006, p. 64-76.

26.CONSTANTINESCU I., DINU A.A., BOSCAIU V., NICULESCU M., Hepatitis Monthly, 14(10):e22072, 2014.
27.ISTRATE,B.,MARECI,D.,MUNTEANU,C.,STANCIU,S.,CRIMU,C.I., TRINCA,L.C., KAMEL,E.,In vitro electrochemical properties of biodegradable YSZ-Coated MgCa Alloy,Environmental engineering and managementjournal,15(5),2016,955-963

28. BARBINTA ,C.A., EARAR, K., CRIMU, C.I., In vitro evaluation of the cytotoxicity of some new titanium alloys, Bioceramics, Vol25, Book series:Key Engineering Materials, Vol 587,2014,303

29.CIOATA, R., BALAN,A., ANTOHE,M.E.,SAVIN,C., IGNAT,G., BASNO,A., Researches Regarding New Biomaterials Involved in Sports Mouthguard, Mat. Plast., 53 , no. 1, 2017, p. 147

30.LIVAK K.J., SCHMITTGEN T.D., Methods, 25(4), 2001, p. 402-408.

31.BENEA H., TOMOAIA G., SORITAU O., PASCA R.D., Romanian Biotechnological Letters, 21(4), 2016, p. 11735-11743.

32.MICULESCU F., BOJ IN D., CIOCAN L.T. et al., JOAM, 9(11), 2007, p.3303-3306.

33.EARAR, K., GRADINARU, S., PARIZA, G. et al., Rev. Chim. (Bucharest), 68, no. 8, 2017, p. 1868.

34.MITACHE, M.M., CURUTIU, C., RUSU, E. et al., Rev. Chim. (Bucharest), 68, no. 3, 2017, p.566.

35. ANDERS S., VOLZ M., FRICK H., GELLISSEN J., Open Orthop J., 3(7), 2013, p. 133-143.

36.KOHLI N., WRIGHT K.T., SAMMONS R.L., JEYS L., SNOW M., JOHNSON W.E., Cartilage, 6(4), 2015, p. 252-263

Manuscript received: 5.10 .2017 